\title{
Lumen
}

Selected Proceedings from the Canadian Society for Eighteenth-Century Studies

\section{Two Early Versions of La Reine de Golconde of Boufflers}

\section{Alexander Sokalski}

Volume 12, 1993

URI : https://id.erudit.org/iderudit/1012581ar

DOI : https://doi.org/10.7202/1012581ar

Aller au sommaire du numéro

Éditeur(s)

Canadian Society for Eighteenth-Century Studies / Société canadienne d'étude du dix-huitième siècle

ISSN

1209-3696 (imprimé)

1927-8284 (numérique)

Découvrir la revue

Citer cet article

Sokalski, A. (1993). Two Early Versions of La Reine de Golconde of Boufflers.

Lumen, 12, 81-88. https://doi.org/10.7202/1012581ar

Copyright (C Canadian Society for Eighteenth-Century Studies / Sociéte canadienne d'étude du dix-huitième siècle, 1993
Ce document est protégé par la loi sur le droit d'auteur. L'utilisation des services d'Érudit (y compris la reproduction) est assujettie à sa politique d'utilisation que vous pouvez consulter en ligne.

https://apropos.erudit.org/fr/usagers/politique-dutilisation/ 


\section{Two Early Versions of La Reine de Golconde of Boufflers}

Published anonymously in the summer of 1761, La Reine de Golconde appears to have enjoyed such a 'succès d'étonnement ${ }^{1}$ that the abbé de Périgord, better known as Talleyrand to future generations, aspired to be known as its author and even attempted to pass himself off as such in contemporary Parisian society until confronted by the real author, the chevalier de Boufflers. Emblemized by this anecdote, recounted by Nesta Webster and which she claims to have translated from the Mémoires of the Marquise de Créquy, ${ }^{2}$ the success of Boufflers's short story was very real indeed and is confirmed by the number of separate editions between the date of its first publication and 1780, the date of the first edition of the Chevalier's CEuvres. Martin, Mylne and Frautschi list eight such separate editions in their Bibliographie du genre romanesque, 1751-1800; they further indicate that the 'conte' is to be found in four contemporary anthologies ${ }^{3}$ and, after 1780, in all of the printed editions of the author's CEuvres, which in their entry total fourteen. In his Anthologie du conte en France, 1750-1789: Philosophes et coeurs sensibles, Angus Martin amends his and his colleagues' earlier figures slightly; here he claims that the short story was reedited a dozen times between its appearance and the end of the century and that it appeared almost twenty times in the editions of Boufflers's CEuvres. ${ }^{4}$

Shortly upon the publication of the original octavo edition the Reine de Golconde was republished in the September 1761 issue of the Mercure de France with the heroine's name as the title. A note at the bottom of the first page of text as printed by the periodical indicates that '[il] a couru différentes copies manuscrites' of Boufflers's story. The author/editor then assures that his version is 'la plus fidelle.' It is, in truth, nothing of the sort; the text presented is a highly bowdlerized, expurgated version of that of the original edition. ${ }^{5}$

A third version, which I shall call truncated, in order to distinguish it from the original and the one just mentioned, became current after 1763 . It first appeared in the collection of Contes moraux of mademoiselle Uncy, where it has the unusual title 'La Nouvelle Paysanne parvenue, ou la courtisane devenue philosophe.' This version does not follow that of the Mercure de France, as Martin, Mylne and Frautschi seem to suggest, but 
rather presents a text amputated of the first four paragraphs of the original edition. It should be noted that the expurgated version has the preamble excised as well and this may well account for MMF's impression that they were dealing with the same versions. This latter, truncated, version is the one to be found in all the contemporary anthologies. I should add that both the truncated and the expurgated versions do not reproduce the liminal verse epistle of the original edition.

Although it cannot be maintained with any degree of certainty that there is a connection between the truncated text and the baron Grimm's criticism of Boufflers's short story: 'Je n'aime pas le préambule qu'on y a mis,' the connection, to me, seems extremely probable. Grimm explains his reaction by adding: 'L'auteur y dit qu'il a composé ce conte pour charmer la solitude et l'ennui de sa retraite, et cela gâte un des plus jolis traits de la fin du conte, où il dit: 'Le lecteur aura peut-être cru que c'est à lui que je parlais, etc.' ' (Corr. litt. 4: 471). Grimm's opinion must have reflected the considered and prevalent feeling of the enlightened eighteenth-century reader and the judgement of this reader, bandied about in the Parisian salons of the day, must surely have appeared vigorous enough to the author himself to motivate him to correct his text by amputating it of the preamble. Boufflers's responsibility for the truncated version is, to my mind, unequivocal, ${ }^{6}$ for it is this version that will be adopted by the official edition of the poet's works published under the title Poésies et pièces fugitives diverses by Desenne in 1782. It will remain the version given in all official editions until the 1803 set of his CEuvres, '[s]eule édition avouée et corrigée par l'auteur,' which signals a return to the text of the original 1761 edition.

It may be that on first reading, the preamble appears to contradict what the narrator states towards the end of the short story as Grimm points out. However, to me, this contradiction is only apparent for these four introductory paragraphs are an integral part of the oneiric discourse of $L a$ Reine de Golconde and as such are consistent with its narrative logic of seemingly unconnected sequences and events, of suppressed transitions as well as with its allegorical intent. When these four paragraphs, an invocation to the power of the word and the irresistible impulse of inspiration, are removed as part of the text, the narrative is drained of much of its power and, additionally, I believe, of its dream-like atmosphere. But as the eighteenth-century reader was probably most interested in the linear development of the story, this amputation may not really have concerned or affected him. That it eventually did bother the author is apparent by the restoration of the preamble in the official 1803 edition.

The expurgated version of La Reine de Golconde published in the Mercure de France presents a quite different situation. It is clear that here the author has had nothing to do with the expurgation. Once again, and 
in fact in the very same entry as that mentioned earlier, the baron Grimm was moved to make a judgement call; after hailing this periodical version as a 'chef-d'œuvre de bêtise et d'impertinence,' he remarks that the author of this expurgated version, 'a voulu rendre le conte de la reine de Golconde décent; mais décent à pouvoir être lu pour l'édification des séminaires où il a été composé, et des couvents de religieuses.' He concludes his short diatribe with the rather withering observation: 'Les changements auxquels ce projet l'a obligé à chaque ligne sont, pour la platitude et la bêtise, une chose unique en son genre' (Corr. litt. 4: 471).

Grimm exaggerates in claiming that on every line of the new text there is a change. In fact, one has to wonder if the Baron ever actually read the Mercure version. In my own review of the changes, I find most of them to be fairly minor, ${ }^{7}$ being mainly changes in punctuation, in capitalization, in tense; a number deal with style, some with propriety and decorum (for example, 'fut tué en duel' becomes 'mourut') or with modesty and decency ('bonne amie' is substituted for 'bonne Jouissance'). Only once have I found a critical comment, veiled though it is in the original, editorially excised. ${ }^{8}$ Ironically this excision is followed almost directly by a genuine editorial blunder. ${ }^{9}$ There are, however, four crucial moments where the original text has undergone major revisions greatly affecting the general tenor of Boufflers's short story and which would certainly suffice to explain Grimm's negative assessment.

In the original version of La Reine de Golconde, the seduction of the eponymous heroine is all innuendo. It is deliciously and playfully titillating. Little is stated; much, if not all, is suggested:

ALINE voulut se défendre de mes caresses, \& dans les efforts qu'elle fit, son pot tomba \& son lait coula à grands flots dans le sentier. Elle se mit à pleurer, \& se dégageant brusquement de mes bras, elle ramassa son pot \& voulut se sauver. Son pied glissa sur la voye lactée, elle tomba à la renverse; je volai à son secours, mais inutilement. Une puissance plus forte que moi m'empêcha de la relever \& m'entraîna dans sa chute. ..... J'avois quinze ans \& ALINE quatorze. C'étoit à cet âge \& dans ce lieu que l'Amour nous attendoit pour nous donner ses premieres leçons. (13-14)

Of this wonderfully delicious scene, Jacques Barchilon writes: 'Moment plein de "candeur», ... premier moment d'une volupté sexuelle ....' ${ }^{10}$ However, to discern in the remembrance of this moment and in the future search for it 'des accents proustiens,' as Barchilon goes on to do, is to exaggerate.

Except for changes in verb tense, the author/editor of the Mercure retains essentially the same text cited above until the moment the heroine picks up her jug. His text then continues: 'elle ramassoit son pot, \& 
menaçoit de se sauver, lorsqu'elle apperçut sa mère. 'Je suis perdue!' s'écria-t-elle, en soupirant. Adieu; gardez-vous de me suivre, car elle me battroit ...' (17-18). In this new version there is no seduction, not even the hint of one, and, this being the case, the remainder of the text is consequently altered to reflect this new reality. Yet the periodical's version does retain at least one incident from the aftermath of the original seduction scene, which to my mind is quite bizarre, and which I must conclude is inadvertent; I think specifically of the gift of money which becomes immensely gratuitous given the new circumstances. What is more important, however, is that in the end the 'volupté sexuelle' Barchilon remarks on in the original version of this scene has completely disappeared. In fact, no longer is the text informed by what Angus Martin has called, '[l]e libertinage léger et élégant du XVIIIe siècle, avec sa pointe d'ironie désabuséee et ce subtil mélange de précisions érotiques et d'allusions ...' (Anthologie 218).

The second apparition of Aline is as the worldly Marquise de Castelmont. The narrator meets her face to face outside the Opera House as they both await the arrival of their carriages. He fails to recognize her; to jog his memory she shows him the ring he offered her on their first meeting and suggests that he accompany her home in her carriage. En route she recounts her story. The remaining recastings of Boufflers's original text by the Mercure author all occur within this intercalated first-person récit.

Firstly, the Mercure text alters entirely the role of the so-called 'aunt.' In the original text, after Aline is rejected by her parents once her pregnancy becomes noticeable, she is taken in by one of those elderly ladies, here from a neighbouring village, that eighteenth-century fiction seems to be filled with: 'Elle me servoit de mere, \& je lui servois de niéce; elle eut soin de me parer \& de me produire; je répétois souvent par son ordre les leçons que vous m'avez données ...' (21). In the Mercure version the light tone of the original is homogenized into a kind of flat banality where linearity triumphs over suggestiveness:

Je fus enfermée, rouée de coups; \& après avoir trouvé le secret de m'échapper de la maison, je m'en allai, demandant l'aumône, à la Ville voisine, où une Dame entre deux âges, \& touchée de ma figure, me retira. Elle me servit de mere, \& je lui servis de niéce. Elle eut soin de mon éducation, de me parer, de m'inspirer des sentimens au-dessus de ma naissance .... (20)

In this revision then not only have the most endearing qualities of Boufflers's text evaporated into thin air but the procuress has also been metamorphosed into a kind of good Samaritan.

Changed, too, are the conditions of Aline's marriage. In the Mercure text Aline secretly marries M. D...., the 'Rapporteur' of her aunt's court case who has become deeply enamoured of her. He, in order to devote 
himself more completely to her, quickly renounces his profession and buys a title, that of Comte de Castlemont. The original version, on the other hand, seems almost to insist on the fact that for a number of years the heroine has lived the life of a high-priced tart. Only when she inherits from her deceased 'aunt' does she decide to change professions, to become an 'honnête femme.' She begins by having drawn up for herself a proper genealogy. Having made it in society, only then does she marry the Marquis de Castelmont, 'un homme de naissance, riche de plus de cent mille livres de rente ...' (23). In passing, I would note the rather curious change in the husband's title, from 'Marquis' in the original version to 'Conte' in that of the Mercure.

The Mercure's editor's sense of propriety and decency, already apparent in the preceding reworkings, is to be observed as well in the fourth revision, the finale of the return from the Opera. Whereas in the original the narrator uses, as he says, 'de [ses] droits,' in the Mercure revision, the elderly husband arrives home in the nick of time to save his wife's perhaps-too-facile virtue: 'je survêcus à toute la Compagnie; \& comptois bien user de mes droits, lorsque le carosse de Monsieur se fit entendre. Je sortis en soupirant, avec l'espérance d'être moins malheureux le lendemain' (22). But as bad luck and the logic of the narration would have it, tomorrow our hero has to report back to the army. To me, the hero's brusk departure in the original version is a question of narrative logic alone, luck, either bad or good, having nothing to do with it.

In the citation from the Correspondance litteraire quoted earlier, the baron Grimm observed that Mercure's author's intention seems to have been to make the story clean enough to be read by seminarians and nuns. While it is probably true that a sense of decency and discretion did incite this author/editor to deemphasize all that was innuendo and suggestiveness in Boufflers's text, I would argue that this author's expurgation of the original text, although very likely also an attempt to satisfy the sensibilites of a varied readership, has broader, more important implications. In my opinion, it is not so much the moralizing as it is the edifying function of expurgation that enters into play here; the text was apparently expurgated in order to emphasize the philosophical content of the story and its instructional aspect. However, in the process, the editor seems to have misinterpreted the text and to have forgotten, or perhaps he never really recognized it, that the secret of lightness, suggestion, innuendo is precisely to transform what is not said into the real subject and the narration into an allegory. ${ }^{11}$

The author of the review published in volume 5 of the Année litteraire of 1761 directs his reader's attention to the resemblance between the conclusion of Voltaire's Candide and that of Boufflers's Reine de Golconde. 'Cette fin - he writes - ressemble à celle de Candide; mais ce trait de similitude 
ne mérite pas la peine d'être relevé' (1273). He is off the mark in his expressed belief that the parallel is not worth noting. It is. Moreover, I believe that he has somewhat misread Boufflers's 'élégance souriante' ${ }^{12}$ which, the reviewer of the Journal encyclopédique, on the other hand, seems to have perceived intuitively albeit perhaps not very clearly:

On pourra se plaindre que la pudeur ne soit pas assez ménagée dans ce Roman. On trouvera le fonds trop petit, trop commun, \& les incidens paroîtront peut-être sans vraisemblance. Mais une narration vive, des descriptions riantes, des réflexions fines, du sentiment, un stile aisé, brillant, animé, le ton Philosophique qui s'y trouve souvent, obtiendront grace pour les défauts, \& tout lecteur délicat le placera au rang des plus jolis Contes qui aient paru de nos jours. (1er octobre $1761,108)$

With both reviewers, just as with the author/editor of the Mercure version, there seems to be a lack of comprehension of what Barchilon calls the short story's 'agréable combinaison de philosophie et de sensualité' (108) and which is the very source of its deeper meaning. As suggested by the citation from the Année litterraire, this deeper meaning of La Reine de Golconde has to do with the search for happiness, that obsessional and preeminent of eighteenth-century themes.

In 1925, in his monumental introduction to a new edition of Rousseau's Nouvelle Héloise, the other capital success of 1761, Daniel Mornet noted that the libertines used wit and forms of style as refinements rather than as 'pudeur.' 'Et c'est en partie une révolte de la pudeur et de la dignité,' he concluded, 'qui explique la fortune contemporaine du roman moral et philosophique. ${ }^{14}$ In his 1974 study Morality and Social Class in Eighteenth-Century Literature and Painting, Warren Roberts comments with greater nuance that, ' $[\mathrm{w}]$ riters and artists executed both moralistic and erotic works, because both were fashionable within the same audience. ${ }^{15}$ The original and the expurgated version of Boufflers's Reine de Golconde would appear to illustrate the very simultaneity of these two conventions even though Boufflers as author is certainly not responsible for the latter version. The surface libertine atmosphere of wit and refinement of the original is a mask for its allegory; the Mercure expurgation lays bare the philosophical message. It is the former, however, which despite its suggestiveness and what might be considered its infringements of decency leaves us with the sense of something concerning our deepest selves having been recounted, and, of course, it is this version that triumphed.

\section{ALEXANDER SOKALSKI}

University of Saskatchewan 


\section{Notes}

1 Octave Uzanne, notice bio-bibliographique, Contes du chevalier de Boufflers (Paris: A. Quantin, 1878) xv. Uzanne goes on to state: 'Ce fut une fureur pendant plus de six mois; $d$ 'innombrables copies d'Aline couraient de ruelle en ruelle, de salon en salon, de société en société; on s'arrachait ces manuscrits, on ne parlait que du conte et de l'auteur ....... Toutes les femmes voulurent connaître l'heureux amant de la jolie laitière, cet écrivain simple et charmant qui avait su, par la fraîcheur et la jolie tournure de son style, exciter la curiosité d'un public blasé par les fadeurs de tant de petits romans' (xvi).

2 The Chevalier de Boufflers: A Romance of the French Revolution (New York: Dutton, 1916) 56. I have been unable to find the original anecdote in the Mémoires of the Marquise de Créquy, which, I should add, are more than likely apocryphal. However, I firmly believe that Webster did not simply invent this anecdote; she must have found it somewhere. I cite it here only as an emblem of Aline's resounding success.

3 MMF do seem unaware of a fifth anthology, the 1775 Journal de lecture, attributed by Barbier to de Lizern; the Boufflers short story is found in 3: 245-67.

4 (Paris: 10/18, 1981) 219. Vivienne Mylne discusses some of the problems raised by evaluating a work's popularity through the number of re-editions in her article 'Re-editions as a Guide to the Assessment of Public Taste in Fiction,' Studies in the French Eighteenth Century Presented to John Lough (Durham: U of Durham P, 1978) 128-140. Over the next two centuries Boufflers's extremely successful 'conte' would inform other works of fiction and become the source of various non-literary texts. Just a few years after its appearance the work was already so deeply entrenched culturally that the Mémoires secrets de Bachaumont conclude an anecdote on Madam Geoffrin and the King of Poland with an intertextual reference: 'C'est l'ingénieuse fiction d'Aline réalisée' (21 mai 1766; 3: 32). I have also found reference to a ship named 'La Reine de Golconde' (Mercure de France, janvier 1786, 36). Within some thirty years of its publication, Boufflers's French text had received both an Italian (1789) and two Russian (1788 and 1792) translations and had been transformed and adapted intertextually in L'Histoire des Amoureux de Quimpercorentin, published in two installments in the Bibliothèque universelle des romans in January and March 1777. In the meantime, only four years after its appearance, Sedaine used the Golconda episode of the short story as the basis of the libretto for his 'ballet-héroïque', Aline, Reine de Golconde. This libretto, parodied by Desfontaines under the title Nanine, soeur de lait de la reine de Golconde (1773), was translated into Swedish in 1776 and later served as the basis for that of Felice Romani's Regina di Golconda, itself set to music by Donizetti. Meanwhile, in 1803 (November 15), Berton's opera Aline, reine de Golconde was premiered and a new score by Boieldieu appeared in 1808 . In the early twentieth century, Anatole France cites the story's title in his Révolte des anges; it will be recalled that one of his rebellious angels is composing an operetta based on the eighteenth-century text.

5 Needless to say I do not agree with Angus Martin who writes that the short story first appeared in the Mercure galant and then as a separate publication (Anthologie 219). A number of factors plead against his chronology: the Mercure's title, Aline; Grimm's entry of 15 July 1761 in his Correspondance littéraire, philosophique et critique, ed. Maurice Tourneux, 4 (Paris: Garnier frères, 1878) 443, which would indicate, as his nineteenth-century editor suggests, that the Baron was sending along a pre-publication copy of the short story to his correspondents and, especially, the baron's later entry in September where he speaks most disdainfully of the Mercure version. 
6 This also appears to have been the opinion of Octave Uzanne, who, in the 'notice bio-bibliographique' to his edition of the Contes, justifies the choice of the 1761 edition as his base text with this comment: 'Pour Aline, nous avons restitue le texte de l'édition originale de 1761, que son auteur, par la suite, avait meurtri en croyant le corriger' (lxxiii).

7 In his edition of the short story Simon Davies details the textual revisions but neglects the changes in capitalization and punctuation, etc.; Aline, Reine de Golconde, Textes littéraires 26 (Exeter: U of Exeter P, 1977) 21-24.

8 'Les coffres des Particuliers \& ceux de l'État étoient également pleins. Le paysan cultivoit sa terre pour lui, ce qui est rare; \& les Trésoriers ne recevoient point les revenus de l'État pour eux, ce qui est encore plus rare.' See La Reine de Golconde (Paris, 1761) 28-29; subsequent citations are from this original edition unless indicated otherwise.

9 The phrase 'les Grands étoient enchantés à la Cour' (29) of the original version comes out as 'Les Grands enfin étoient enchaînés à la Cour' in the Mercure version (14).

10 Le Conte merveilleux français de 1690 à 1790: Cent ans de féerie et de poésie ignorées de l'histoire littéraire (Paris: H. Champion, 1975) 109.

11 In his Preface to a deluxe edition of Boufflers's text, Camille Mauclair writes: 'Nous avons oublié surtout le secret de certains silences, qui sont les pudeurs de l'explication d'âme et qui font, de ce qui n'est pas dit le sujet caché, transfigurateur, des histoires allégoriques'; Aline, Reine de Golconde (Paris: A. Ferroud, 1901) xii.

\section{Angus Martin, Anthologie 218.}

13 I am inclined to agree with Nicole Vaget Grangeat's analysis of this theme as it informs Boufflers's short story, an analysis that surprises in an otherwise mediocre study. Like Rousseau, according to her, Boufflers believed that human happiness was to be found in nature; however, unlike Rousseau, Boufflers proposes a happiness founded on companionship, wisdom, enjoyment, a happiness in the image of a diamond: 'Ce bonheur ainsi réalisé est semblable au diamant; à l'opposé du plaisir qui disparaît très vite, le bonheur dure, ne perd ni son brillant ni sa valeur et résiste aux vicissitudes du temps' (Le Chevalier de Boufflers et son temps: étude d'un échec [Paris, Nizet, 1976] 145). Golconda, that Indian city famed for its diamond mines, this critic adds, is thus synonymous with the precious stone and the title of the story should be read as: 'Aline, ou celle qui détient le secret du bonheur' (146), for it is Aline, the former Queen of Golconda, who reveals to the narrator that happiness is reserved for those who are wise enough to leave off worldly ways and that it is something to be shared. One could perhaps extend this analysis to have it encompass both the form and style of the short story, the one mirroring the facets of a cut diamond, the other its resultant brilliance and light. However, Vaget Grangeat's interpretation takes no account of the variant versions of the text nor of the story's variant titles. Today it is known by the title Aline, Reine de Golconde, a title which appears to have come into use only after 1799 with that year's edition of the CGuvres. Up to 1799 all editions use the original title La Reine de Golconde, except for the official Poésies et pièces fugitives where it has become Aline, ou la Reine de Golconde. The author must have reconsidered his title just as he rethought the reinclusion of the preamble in the definitive version; he must have intuited both changes as necessary to his allegorical intent.

14 (Paris: Hachette, 1925) 44.

$15 \mathrm{U}$ of Toronto Romance Series 25 (Toronto: U of Toronto P, 1974) 144. 